\title{
LONG-TERM EFFECTS OF IRRIGATION WITH \\ IMPORTED WATER ON WATER LEVELS AND \\ WATER QUALITY
}

By Brian W. Drost, James C. Ebbert, and Stephen E. Cox

U.S. GEOLOGICAL SURVEY

Water-Resources Investigations Report 93-4060

Prepared in cooperation with

STATE OF WASHINGTON DEPARTMENT OF ECOLOGY

Tacoma, Washington

1993

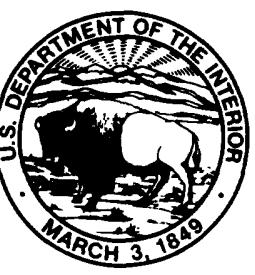




\section{U.S. DEPARTMENT OF THE INTERIOR}

BRUCE BABBITT, Secretary

U.S. GEOLOGICAL SURVEY

Dallas L. Peck, Director

Any use of trade, product, or firm names is for descriptive purposes only and does not imply endorsement by the U.S. Government.

For additional information write to:

District Chief

U.S. Geological Survey

1201 Pacific Avenue - Suite 600

Tacoma, Washington 98402
Copies of this report may be purchased from:

U.S. Geological Survey

Books and Open-File Reports Section

Box 25425 Federal Center

Denver, Colorado 80225 


\section{CONTENTS}

Page

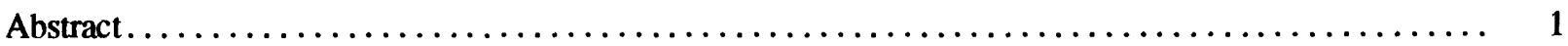

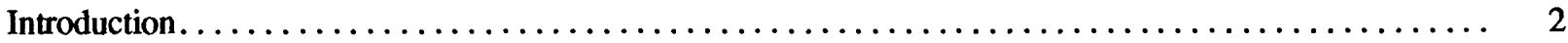

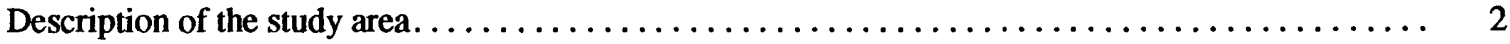

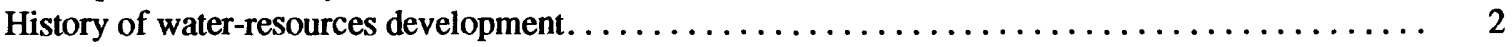

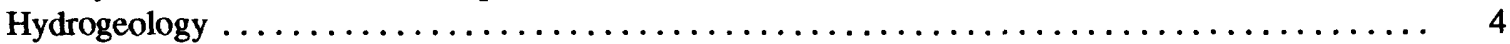

Long-term changes in ground-water levels. $\ldots \ldots \ldots \ldots \ldots \ldots \ldots \ldots \ldots \ldots \ldots \ldots \ldots \ldots \ldots \ldots \ldots, 8$

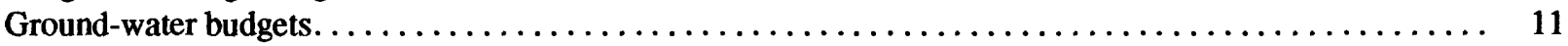

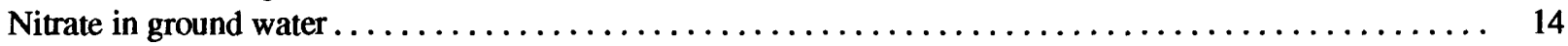

Imported irrigation water as a source of nitrate in ground water $\ldots \ldots \ldots \ldots \ldots \ldots \ldots \ldots \ldots$

Naturally occurring sources of nitrate in ground water. $\ldots \ldots \ldots \ldots \ldots \ldots \ldots \ldots \ldots \ldots \ldots \ldots$

Fertilizers as a source of nitrate in ground water. $\ldots \ldots \ldots \ldots \ldots \ldots \ldots \ldots \ldots \ldots \ldots \ldots \ldots \ldots$

Geohydrologic factors to consider regarding management of water resources $\ldots \ldots \ldots \ldots \ldots \ldots \ldots \ldots, 17$

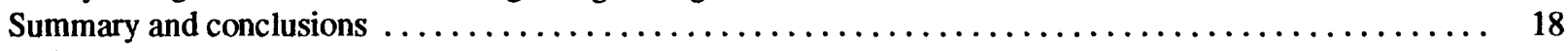

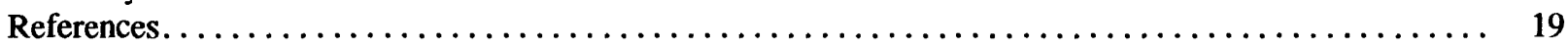

\section{ILLUSTRATIONS}

Page

Figures

1-8. Maps showing:

1. Location of Pasco basin and study area----on 3

2. Water-development areas -

3. Surficial geology of the study area - - 6

4. Water-table altitude, March 1986- 7

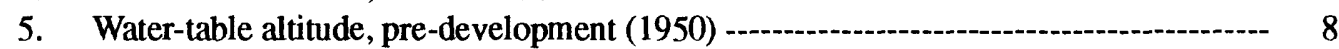

6. Change in water-table altitude, pre-development (1950) to March 1986 -

7. Occurrence of shallow water table - - 10

8. Location of irrigated cropland and wells tested for nitrate-nitrogen concentrations in ground water, September 1986 to November 1989

9. Diagram showing qualitative assessment of expected effects on the ground-water system of selected management alternatives-.-...- 18

\section{TABLES}

Table 1. Methods of calculating values used in ground-water budgets 


\section{CONVERSION FACTORS AND VERTICAL DATUM}

$\begin{array}{lcl}\text { Multiply inch-pound units } & \text { By } & \text { To obtain metric units } \\ \text { inch (in) } & 2.540 & \text { centimeter } \\ \text { foot (ft) } & 0.3048 & \text { meter } \\ \text { mile (mi) } & 1.609 & \text { kilometer } \\ \text { square mile }\left(\mathrm{mi}^{2}\right) & 2.590 & \text { square kilometer } \\ \text { acre-foot }(\mathrm{acre}-\mathrm{ft}) & 1,233 & \text { cubic meter } \\ \text { degrees Fahrenheit }\left({ }^{\circ} \mathrm{F}\right) & { }^{\circ} \mathrm{C}=5 / 9\left({ }^{\circ} \mathrm{F}-32\right) & \text { degrees Celsius }\left({ }^{\circ} \mathrm{C}\right) .\end{array}$

Sea level: In this report "sea level" refers to the National Geodetic Vertical Datum of 1929 (NGVD of 1929)--a geodetic datum derived from a general adjustment of the first-order level nets of both the United States and Canada, formerly called Sea Level Datum of 1929. 


\title{
LONG-TERM EFFECTS OF IRRIGATION WITH IMPORTED WATER ON WATER LEVELS AND WATER QUALITY
}

\author{
Brian W. Drost, James C. Ebbert, and Stephen E. Cox
}

\begin{abstract}
Prior to 1950, the 2,000-mile semiarid Pasco basin of Washington State was dominated by dryland farming. Large-scale irrigation with imported surface water has since transformed the area into one of the most productive agricultural areas in the United States. However, this transformation has come at a price: water logging of soils, landsliding, and large concentrations of nitrate in ground waters.

From 1950 to 1986, in the 660 square miles of the Pasco basin that lie within Franklin County, ground-water levels rose by an average of about 200 feet. Present-day water levels are near land surface in about half of the area, requiring more than 900 miles of buried drains to maintain levels below crop root zones.

The pre-development ground-water budget consisted of inflow from upgradient areas $(26,000$ acre-feet per year) and recharge from precipitation (16,000 acre-feet per year). All pre-irrigation discharge was from the ground-water system to rivers, and equaled the total inflow of 42,000 acre-feet per year.

The present-day ground-water budget totals nearly 300,000 acre-feet per year, with inflow and outflow apparently in dynamic equilibrium. Recharge is from upgradient inflow and precipitation (71,000 acre-feet per year; 24 percent), applied irrigation (89,000 acre-feet per year; 30 percent), and canal seepage (140,000 acre-feet per year; 46 percent). Discharge is to rivers $(47,000$ acre-feet per year; 16 percent $)$, drains $(130,000$ acre-feet per year; 44 percent), springs and seeps (21,000 acre feet per year; 7 percent), and pumping wells $(97,000$ acre-feet per year; 33 percent).

The concentrations of nitrate in ground water have increased by as much as two orders of magnitude over pre-irrigation values. More than 30 percent of the sampled wells yielded concentrations of nitrate (as nitrogen) greater than the drinking-water standard $(10 \mathrm{mg} / \mathrm{L})$. Nitrogen fertilizers are the primary source of the nitrate.

In management of the ground-water system, water levels and water quality need to be considered. Ground-water levels can be lowered by reducing the two largest sources of recharge-canal seepage and applied irrigation but these two inflows have opposite effects on water quality. Canal seepage has nitrate concentrations of about $1 \mathrm{mg} / \mathrm{L}$ (as nitrogen) and tends to dilute nitrate concentrations in ground water, whereas the nitrate concentration of the applied irrigation recharge is more than $20 \mathrm{mg} / \mathrm{L}$ and causes ground-water nitrate concentrations to increase.
\end{abstract}




\section{INTRODUCTION}

The Pasco basin (fig. 1) includes approximately $2,000 \mathrm{mi}^{2}$ of south-central Washington State. Land use in the basin includes dryland and irrigated agriculture, undeveloped rangeland, urban and residential development, and the U.S. Department of Energy's Hanford Nuclear Reservation. Over the past 40 years, much of the basin has been changing from rangeland and dryland farming into one of the major agricultural areas of the United States. Large volumes of water have been diverted from surface-water systems into this area for irrigation.

A variety of water problems have resulted, both directly and indirectly, from the increase in irrigation. The use of imported irrigation water has been linked to significant rises in ground-water levels in many areas. These rises are the result of percolation of water applied to crops and seepage from the distribution system. Rising ground-water levels in some areas have resulted in septic system failures, damage to roads, loss of agricultural land due to ponding, and landslides. Large concentrations of nitrate observed in water from some wells have been linked to application of fertilizers and (or) failure of septic systems.

This report describes the changes in ground-water levels and budgets from pre-development to present day. This report also presents the present-day distribution of nitrate concentration in ground water and discusses the possible sources of the nitrate. A section on geohydrologic factors related to management of the area's water resources summarizes the key aspects of the report for water managers.

\section{Description of the Study Area}

The study area (fig. 1) encompasses about $660 \mathrm{mi}^{2}$ of the Pasco basin, which is one of several basins in the Columbia Plateau province separated by anticlinal ridges. Land-surface altitudes range from about $330 \mathrm{ft}$ to about $1,200 \mathrm{ft}$. The study area is transected by many canyons, coulees, and scablands. These features are the result of catastrophic flooding when ice dams failed and released vast quantities of glacial meltwater during the Pleistocene Epoch. Other features of the study area are landslide deposits, both active and inactive, and sand dunes, both active and stabilized.

The climate is arid to semiarid. Average annual precipitation ranges from 6 to 10 in and occurs primarily in winter. Spring and summer precipitation is mainly in the form of local thunderstorms, and winter precipitation generally falls as light rain or snow. The mean annual temperature is about $57^{\circ} \mathrm{F}$; July is the hottest month $\left(\sim 75^{\circ} \mathrm{F}\right)$ and January is the coldest $\left(-31^{\circ} \mathrm{F}\right)$.

About 60 percent of the study area is used for agriculture (crops, pasture, orchards, and vineyards). The remainder is mostly undeveloped rangeland; residential, urban, commercial, and industrial uses account for only about 5 percent of the land. The study area has a population of about 32,000 .

Alfalfa, wheat, potatoes, and corn are the major crops. Asparagus, fruits, pasture, and barley are significant minor crops. The dominant irrigation method is sprinklers, which are used on about 85 to 90 percent of the irrigated acreage. Most of the rest of the irrigated acreage is served by surface gravity systems. Less than 1 percent is served by drip irrigation.

\section{History of Water-Resources Development}

The earliest development of the study area was grazing and dryland wheat farming with individual domestic and small public-supply wells. The first significant irrigation began in 1909, when the Pasco Reclamation Company (1909-1917) began supplying a small part of the study area with water from the Snake River. In 1922, shortly after the Pasco Reclamation Company went out of business, the Franklin County Irrigation District (FCID) (fig. 2) began supplying water to the same general area from the Columbia River. 


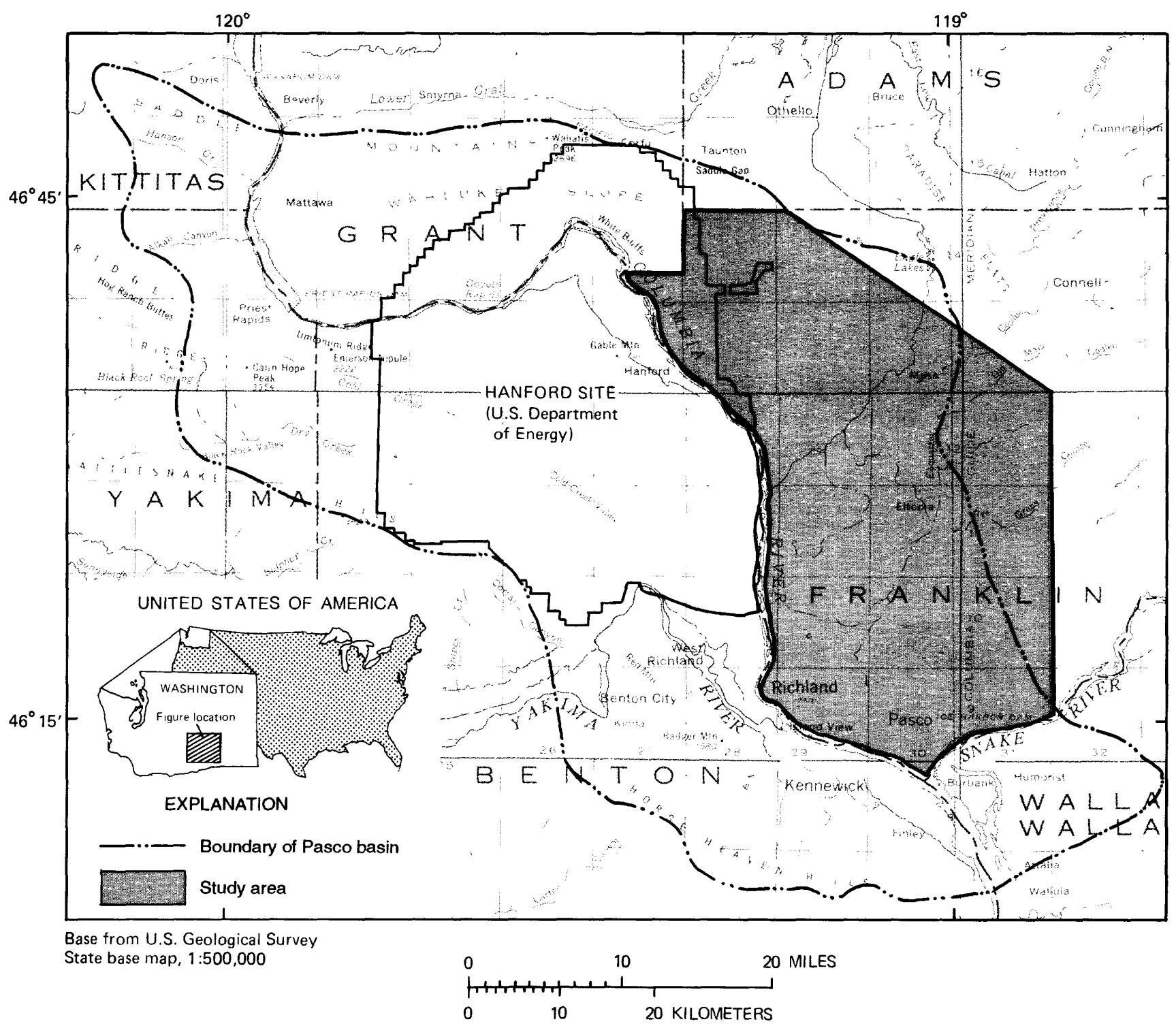

FIGURE 1.--Location of Pasco basin and study area. 
The most dramatic changes occurred when the study area began receiving irrigation water as part of the U.S. Bureau of Reclamation's South Columbia Basin Irrigation District (SCBID) (fig. 2), a part of the Columbia Basin Irrigation Project. SCBID irrigation began in a small part of the study area in 1948 and continued expanding through 1977. All SCBID irrigation water comes from the Columbia River far upstream and outside of the study area.

As the water table has risen to near the land surface in some places, buried drains (perforated pipes) have been installed to stabilize the water table below the root zones of crops. The first buried drains were installed in 1964 . Drain installation continued at least through 1988.

Ground-water pumping for irrigation in areas not supplied with imported surface water has become significant in recent years. Pumping began in about 1973 in what has become known as the Pasco Greenbelt (fig. 2).

\section{Hydrogeology}

The study area lies in the eastern half of the Pasco basin, which is a structural and topographic low. The Pasco basin is underlain by three major stratigraphic units in which all significant ground water occurs. The units, in ascending order, are (1) the Columbia River Basalt Group, (2) the Ringold Formation, and (3) the Hanford formation (informal usage).

During the Tertiary Period, flood basalts flowed intermittently into the Pasco basin, resulting in a total basalt thickness in excess of $15,000 \mathrm{ft}$. Folding and subsidence of the basalt in the Late Cenozoic Era resulted in the deposition of fluvial sediments by ancestral rivers flowing into and through the basin.

These sediments form the Ringold Formation (Pliocene), which consists of four textural facies: sand and gravel; silt and clay; sand, gravel, and silt; and silt and sand. Total thickness of the Ringold Formation exceeds $600 \mathrm{ft}$ in some parts of the study area.

Catastrophic proglacial flooding during the late Quaternary Period resulted in deposition of the Hanford formation in the Pasco basin. The proglacial flood waters cut into the basalts and Ringold Formation sediments and deposited more than $200 \mathrm{ft}$ of sediments in parts of the study area. The Hanford formation has two textural facies (sand and gravel and silt and sand). The surficial (or near-surface) distribution of these units is shown on figure 3.

The sediments above the basalt were delineated into units primarily on the basis of their textures. The coarse-grained units are generally highly productive aquifers wherever they occur. The fine-grained units generally can produce small quantities of water in some locations, but function primarily as confining beds.

The basalts form a complex series of aquifers and confining beds. Ground water in the basalt occurs in joints, vesicles, fractures, and other localized features that result in permeable zones. The greatest permeabilities are in highly vesicular and (or) fractured tops and basal parts of basalt flows. The centers of most basalt flows are dense and have very low permeabilities, and generally act as confining beds.

The general direction of ground-water flow can be inferred from figure 4, which shows the configuration of the water table in March 1986. The contours on figure 4 are based on water-level measurements from approximately 400 wells. Most of the shallow ground-water flow is directed perpendicular to the water-table contours on figure 4, toward the Columbia and Snake Rivers, where it discharges. However, some flow is toward internal drains (canyons and coulees). On a local scale, flow at the water table is frequently toward buried drains. Although the altitude of the water table changes seasonally, the general pattern of flow remains fairly constant. With increasing depth in the ground-water system, flow is oriented more toward the rivers and is less influenced by the internal drains. This is particularly true of the basalt aquifers. 
In addition to lateral flow, there is also vertical flow in the ground-water system between aquifers through the confining beds. In most of the study area, vertical flow is downward. Vertical flow is upward only in very narrow bands along the discharge areas near major rivers.

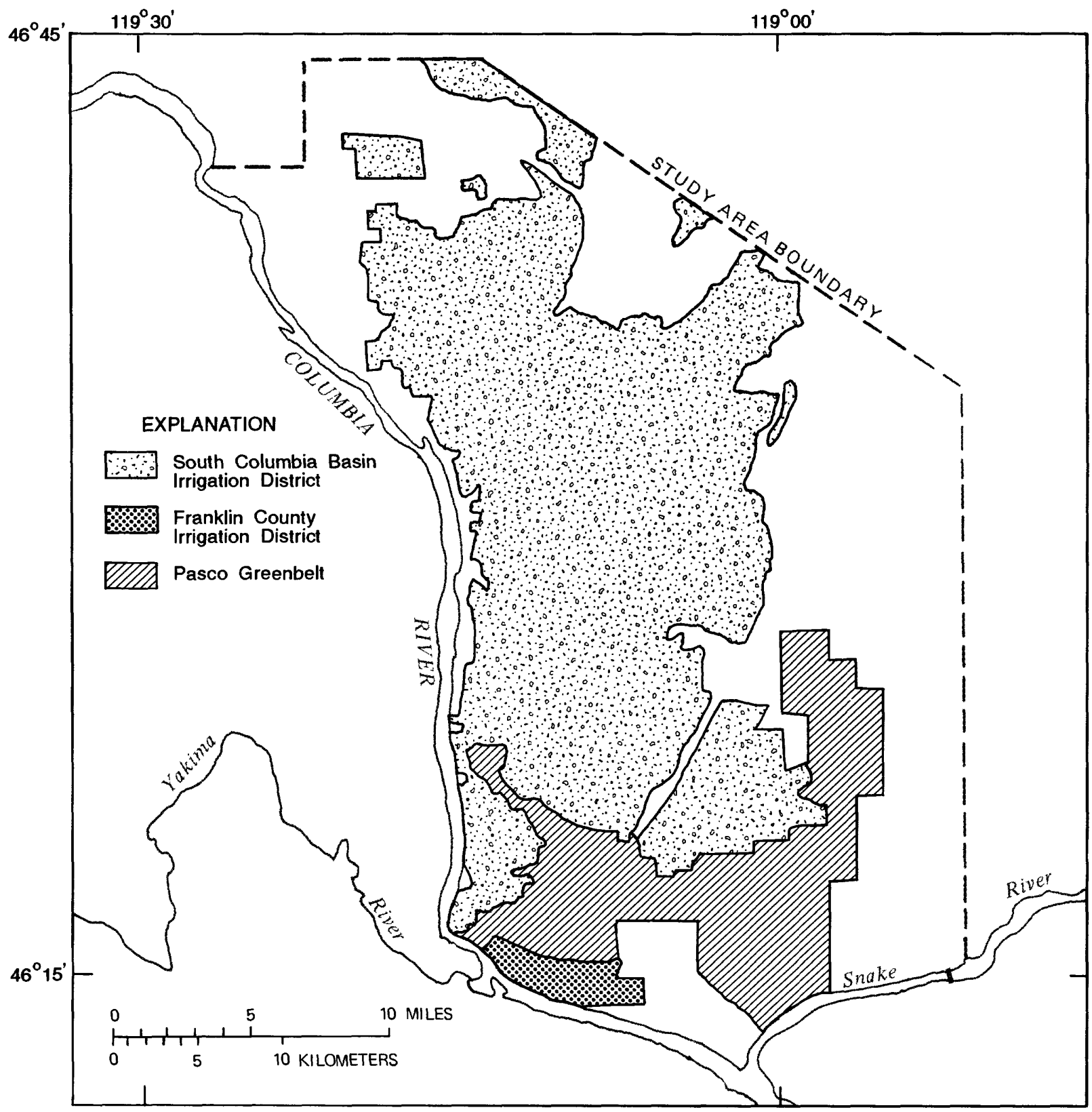

Base from U.S. Geological Survey State base map, 1:500,000

FIGURE 2.--Water-development areas. 


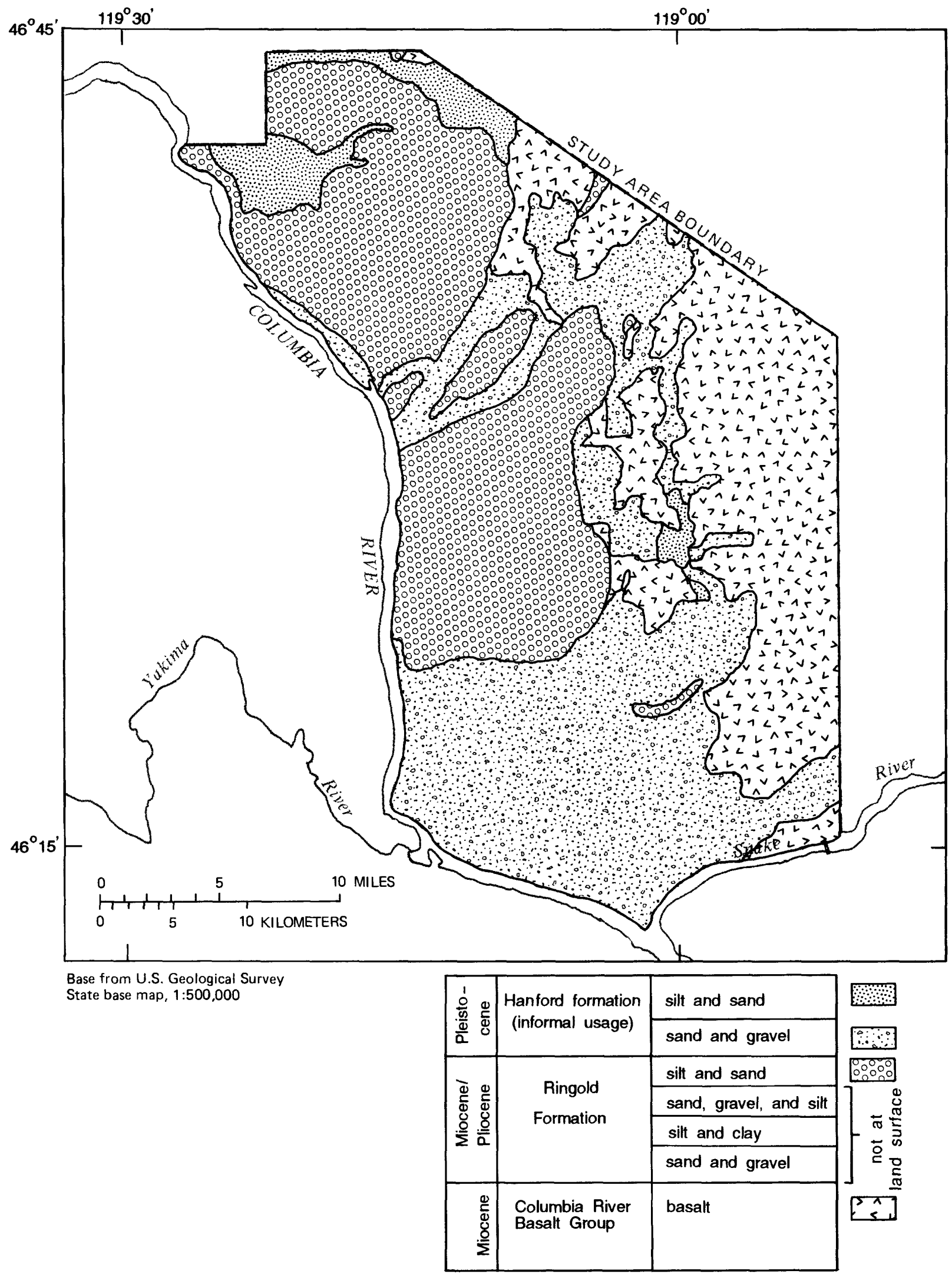

FIGURE 3.--Surficial geology of the study area. 


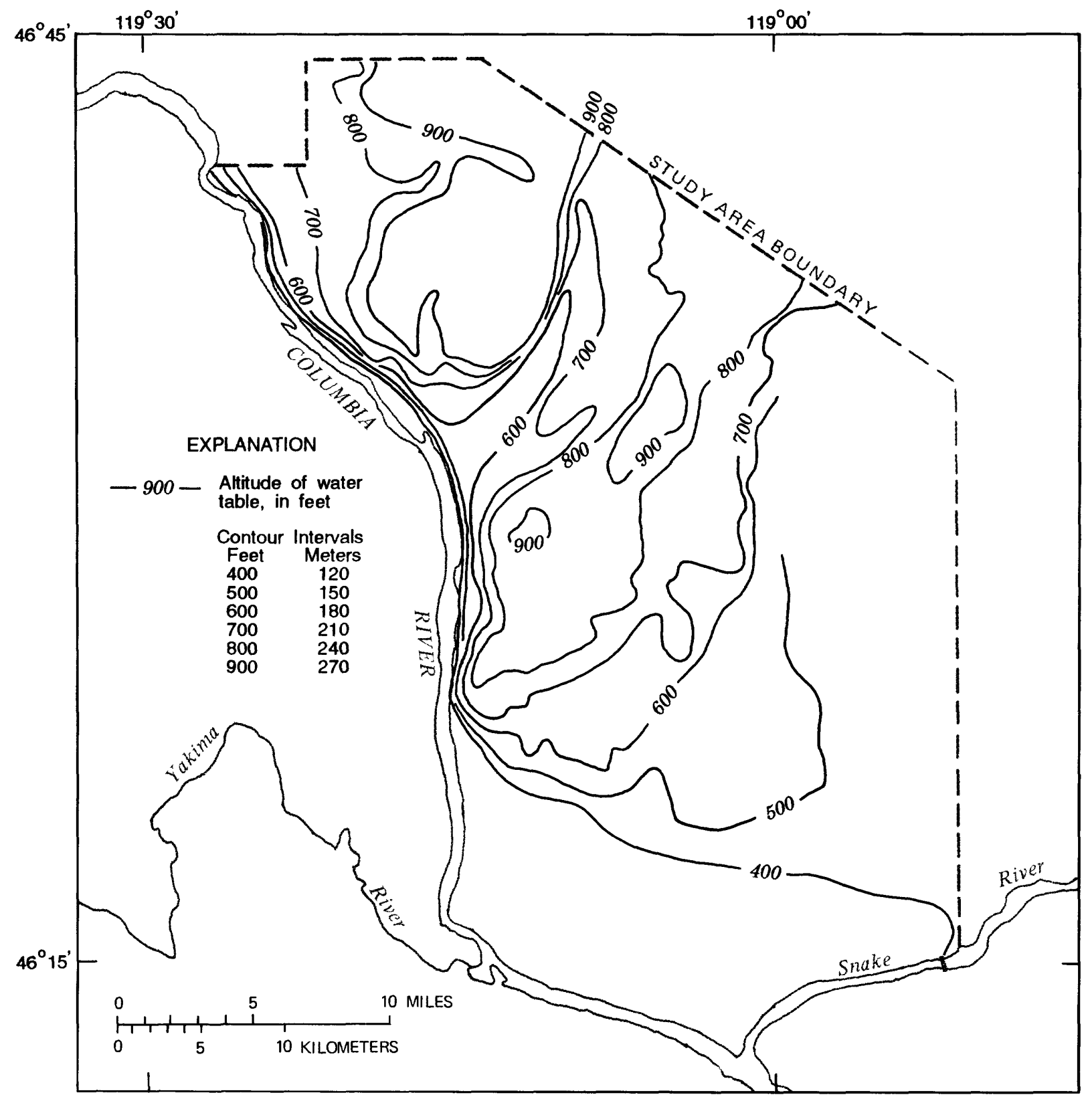

Base from U.S. Geological Survey State base map, 1:500,000

FIGURE 4.--Water-table altitude, March 1986. 


\section{LONG-TERM CHANGES IN GROUND-WATER LEVELS}

The development of the study area's water resources has resulted in dramatic changes in ground-water levels. Figure 5 shows an approximation of the pre-development water table (1950), based on contours for part of the study area from Mundorff and others (1952) and 15 water levels in the rest of the study area. Figure 4 shows the water table as of 1986 (most recent area-wide measurement of water levels). The large changes in the water table from pre-development to 1986 can be seen on figure 6 . As can be seen on figure 7, there are large areas where the water table has risen to, or nearly to, the land surface. Subsurface drains have been installed in most of the areas of shallow water table. The most recent water-level data (1986-1991) indicate that most of the study area has reached a state of dynamic equilibrium.

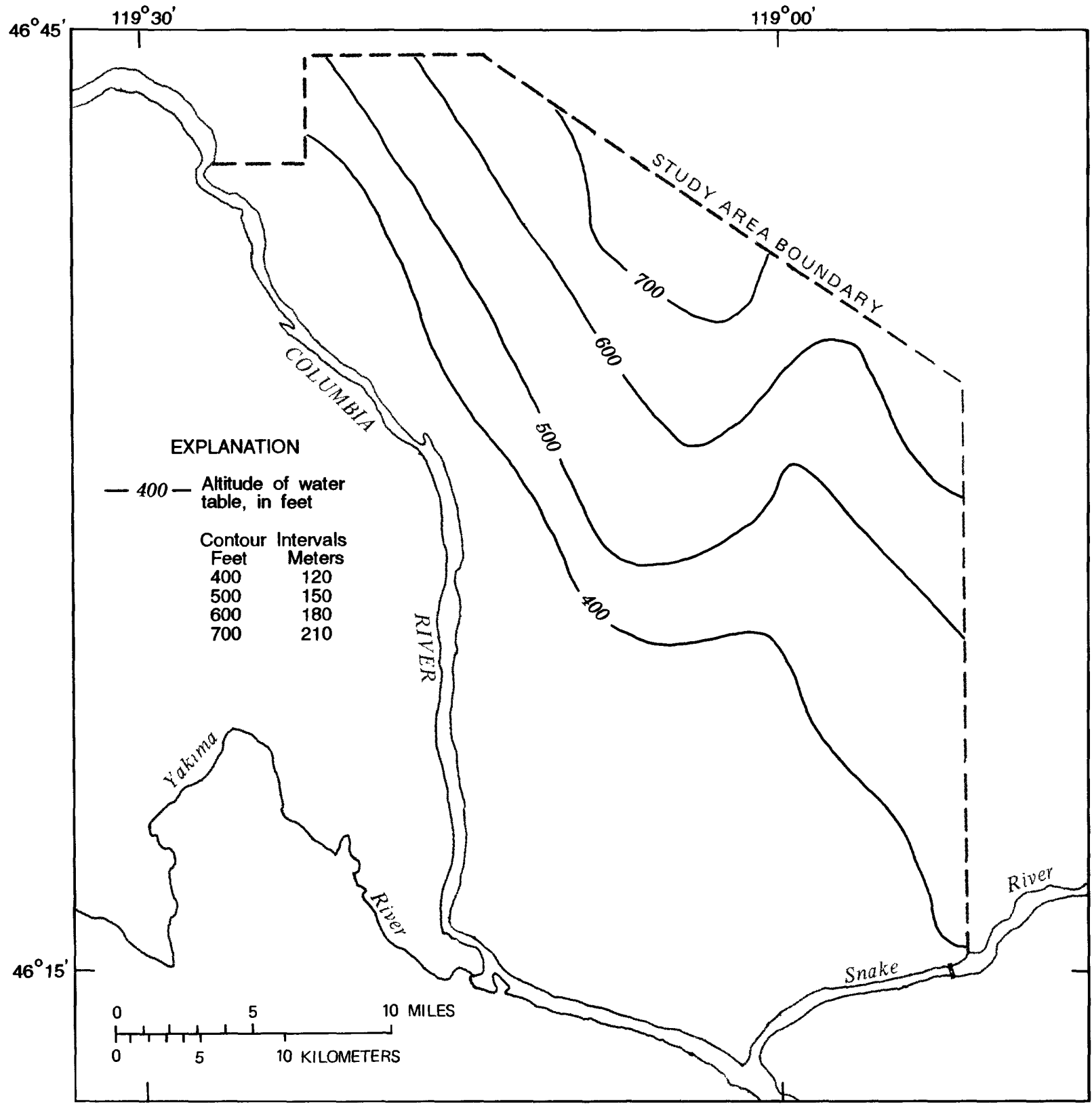

Base from U.S. Geological Survey State base map, 1:500,000

FIGURE 5.--Water-table altitude, pre-development (1950). 


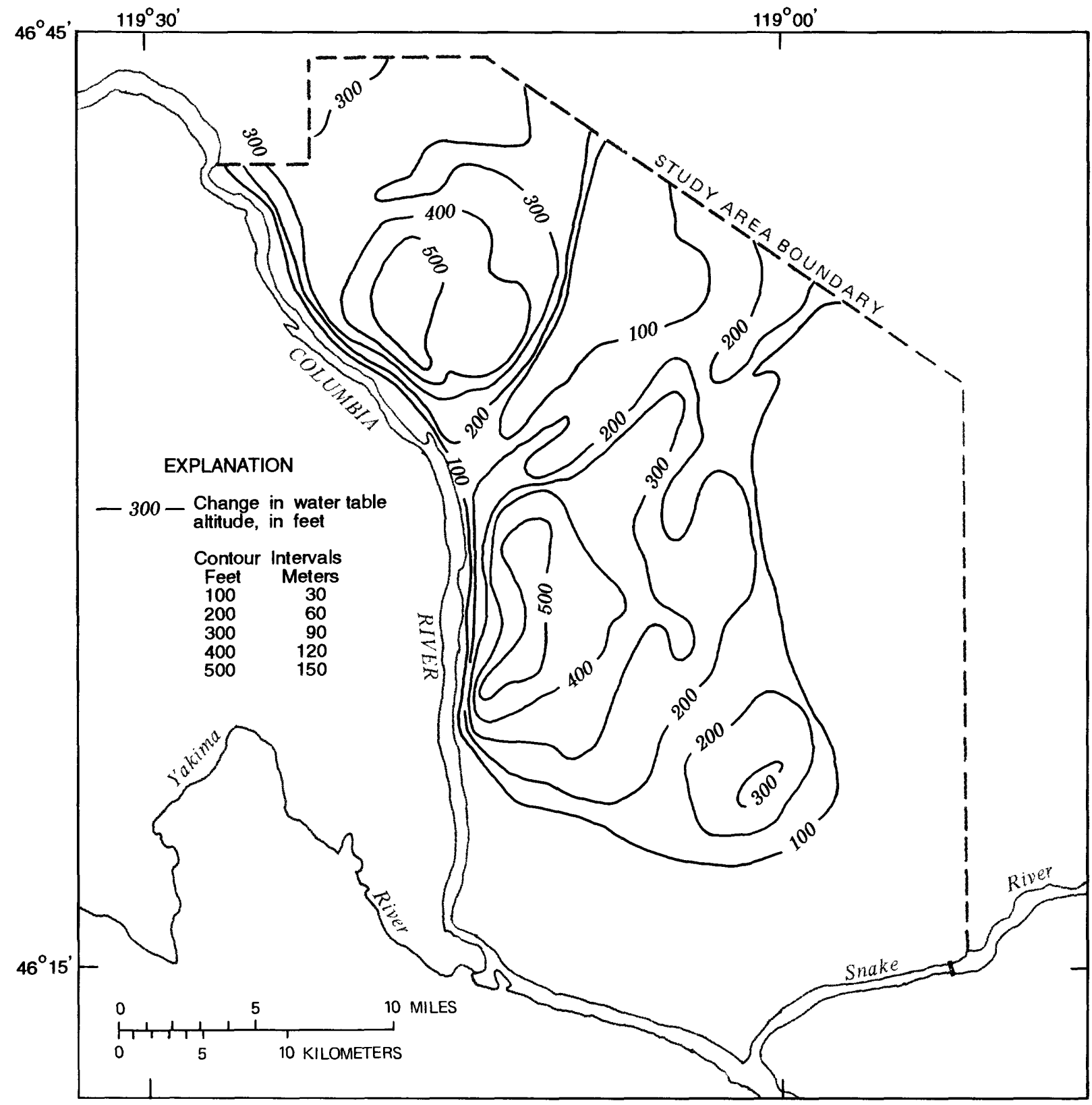

Base from U.S. Geological Survey

State base map, 1:500,000

FIGURE 6.--Change in water-table altitude, pre-development (1950 to March 1986). 


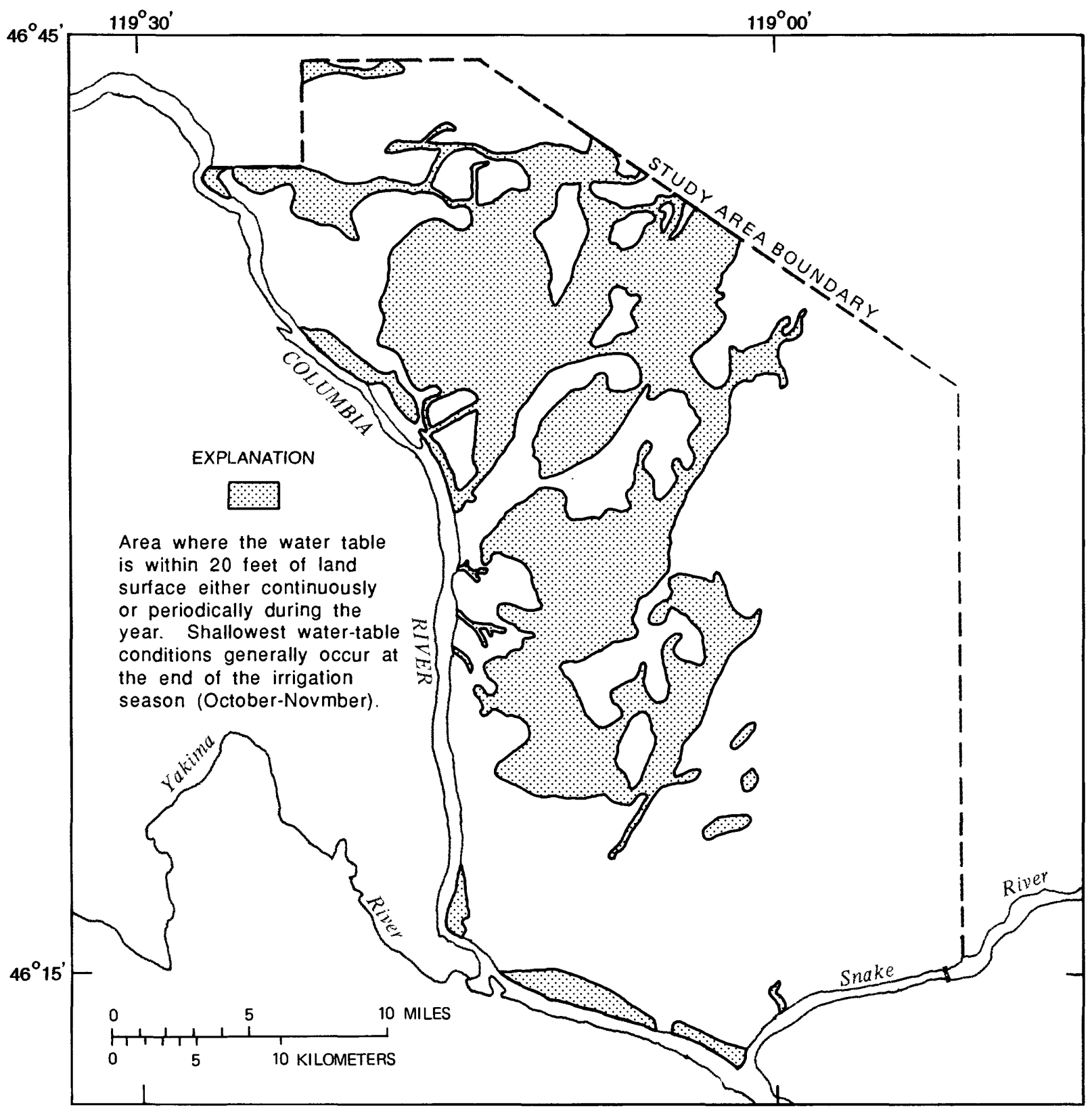

Base from U.S. Geological Survey State base map, 1:500,000

FIGURE 7.--Occurrence of shallow water table. 


\section{GROUND-WATER BUDGETS}

Important insights into the present dynamics of the ground-water system and into how the system has changed with time can be derived from calculation of ground-water budgets for 1986 and for pre-development conditions. Under 1986 conditions, the ground-water budget can be represented by

$$
G W_{i n}+R_{p p t}+R_{i r r}+R_{c a n}=D_{r i v}+D_{d r a}+D_{s p r}+D_{p p g}+\Delta S
$$

where:

$$
\begin{aligned}
& G W_{i n}=\text { ground-water inflow to the study area, } \\
& R_{p p t}=\text { precipitation recharge, } \\
& R_{i r r}=\text { irrigation recharge, } \\
& R_{c a n}=\text { canal-seepage recharge, } \\
& D_{r i v}=\text { discharge to rivers, } \\
& D_{d r a}=\text { discharge to drains, } \\
& D_{s p r}=\text { discharge to springs and seepage faces (includes ground-water evapotranspiration), } \\
& D_{p p g}=\text { pumping from wells, and } \\
& \Delta S \quad=\text { change in ground-water storage. }
\end{aligned}
$$

In addition to ground-water inflow from upgradient areas, the ground-water system is recharged by precipitation, applied irrigation, and canal seepage. Discharge from the ground-water system occurs as flow to rivers, drains, springs, and seepage faces, as evapotranspiration, and by pumping from wells.

Substituting values (table 1) for each of the factors into equation 1 yields the following (all values in thousands of acre-feet per year and rounded to two significant figures):

$$
\begin{aligned}
G W_{i n}+R_{p p t}+R_{i r r}+R_{c a n} & =D_{r i v}+D_{d r a}+D_{s p r}+D_{p p g}+\Delta S \\
47+24+89+140 & =47+130+21+97+\Delta S \\
300 & =295+\Delta S
\end{aligned}
$$

The result indicates that ground-water storage is increasing by about 5,000 acre $\mathrm{ft} / \mathrm{yr}$. However, it should be noted that many of the numbers in the water budget are estimates whose accuracies are uncertain and the calculated storage change represents less than 2 percent of the total flow in the ground-water system. 
Table 1.--Methods of calculating values used in ground-water budgets

\begin{tabular}{|c|c|c|}
\hline Component & $\begin{array}{l}\text { Component } \\
\text { symbol used } \\
\text { in Equation } 1\end{array}$ & Method of calculation \\
\hline $\begin{array}{l}\text { Ground-water inflow to } \\
\text { the study area }\end{array}$ & $G W_{\text {in }}$ & $\begin{array}{l}\text { Darcy's Law using water-level maps (Bauer and } \\
\text { others, 1985), aquifer-thickness maps (Drost and } \\
\text { Whiteman, 1986), and median hydraulic conductivities } \\
\text { (from specific-capacity tests). }\end{array}$ \\
\hline Precipitation recharge & $R_{p p t}$ & $\begin{array}{l}\text { Deep percolation model, using daily values, (Bauer and } \\
\text { Vaccaro, 1987). }\end{array}$ \\
\hline Irrigation recharge & $R_{i r r}$ & $\begin{array}{l}\text { Irrigated area determined from aerial photographs. } \\
\text { Deep percolation rate from soil-moisture model } \\
\text { calibrated specifically for the project area by the } \\
\text { Franklin Conservation District. }\end{array}$ \\
\hline Canal-seepage recharge & $R_{c a n}$ & $\begin{array}{l}\text { Median seepage rates (based on } 35 \text { inflow-outflow } \\
\text { and } 101 \text { ponding tests) were determined for each } \\
\text { combination of canal lining type and underlying geology. } \\
\text { These seepage rates were multiplied by their respective } \\
\text { areas (wetted perimeters times length) for the project } \\
\text { area. }\end{array}$ \\
\hline Discharge to rivers & $D_{\text {riv }}$ & $\begin{array}{l}\text { See } G W_{\text {in }} \text {, using estimated areas of discharge in } \\
\text { place of aquifer thicknesses. }\end{array}$ \\
\hline Discharge to drains & $D_{d r a}$ & $\begin{array}{l}\text { Discharges to open drains from U.S. Army Corps of } \\
\text { Engineers pumping records. Discharges from buried } \\
\text { drains from surface-water budgets of wasteway systems } \\
\text { using U.S. Geological Survey and U.S. Bureau of } \\
\text { Reclamation gaging station records. }\end{array}$ \\
\hline $\begin{array}{l}\text { Discharge to springs and seepage } \\
\text { faces (includes ground-water } \\
\text { evapotranspiration) }\end{array}$ & $D_{s p r}$ & $\begin{array}{l}\text { Measured and estimated spring and seepage-face } \\
\text { flows (Drost and others, 1989; Schuster and Hays, } \\
\text { 1984; and Marrat, 1988). Also includes estimated } \\
\text { ground-water evapotranspiration from seepage faces } \\
\text { based on } 20 \text {-inch/year difference between potential } \\
\text { and actual evapotranspiration (Phillips, 1970). }\end{array}$ \\
\hline Pumping from wells & $D_{p p g}$ & $\begin{array}{l}\text { Irrigated area determined from aerial photographs. } \\
\text { Rate of irrigation from Franklin Conservation } \\
\text { District study. }\end{array}$ \\
\hline
\end{tabular}


Under pre-development conditions, the ground-water budget of the study area can be represented by

$$
G W_{i n}+R_{p p t}=D_{\text {riv }}
$$

In pre-development times, the only inflows to the ground-water system were ground-water inflow from upgradient areas and recharge from precipitation. The only discharge was flow to the rivers. The ground-water system was presumably in equilibrium, and therefore no storage-change factor is needed in the equation.

Substituting values for each of the factors into equation 3 yields the following (all values in thousands of acre-feet per year):

$$
\begin{aligned}
G W_{i n}+R_{p p t} & =D_{r i v} \\
26+16 & =42
\end{aligned}
$$

The ground-water budget of the study area changed dramatically from pre-development time to 1986 . The annual flow through the ground-water system increased about seven-fold, from $42,000 \mathrm{acre}-\mathrm{ft} / \mathrm{yr}$ to 300,000 acre $\mathrm{ft} / \mathrm{yr}$.

In response to this increased flow, the ground-water system had to adjust. The adjustment took place through increased storage of water in the ground (and therefore higher water levels) and a greater rate of discharge from the ground-water system. Comparing equations 2 and 4, it can be seen that recharge increased through time (both in quantity and types), resulting in increases in discharge (both in quantity and types). As of 1986, the ground-water system appeared to be at or near dynamic equilibrium. However, between pre-development time and 1986, huge changes in ground-water storage (and therefore ground-water levels) occurred.

The total increase in ground-water storage, represented by the change in water-table altitudes from pre-development to 1986 (using storage coefficients ranging from 0.006 for the basalts to 0.18 for the gravels of the Hanford formation), is nearly 5 million acre-ft of water. During the primary period of development (1950-1986), the average annual increase in storage was approximately 130,000 acre-ft.

As can be seen from the ground-water budgets, recharge from canal seepage and applied irrigation accounts for almost 90 percent of the increase in inflow to the ground-water system from pre-development to 1986 . These two recharge sources were primarily responsible for the change in storage and rise in water levels in the study area.

The change in ground-water flow from pre-development to 1986 was probably not a linear progression. The recharge from applied irrigation undoubtedly increased as more and more land was irrigated, but the recharge per unit of land probably decreased as irrigators became more efficient, changing from rill irrigation to sprinklers. Recharge from canal seepage certainly increased as more canals were added to the irrigation systems, but the recharge per square feet of canal bed decreased as more of the canals were lined. These changes in the major components of the ground-water system through time are difficult to quantify. However, it is apparent that canal seepage and applied irrigation are responsible for most of the change in water levels. 


\section{NITRATE IN GROUND WATER}

Between September 1986 and November 1989, nearly 400 water samples from more than 200 wells were analyzed for nitrate. Observed nitrate concentrations ranged from less than 0.1 to $100 \mathrm{mg} / \mathrm{L} \mathrm{NO} \mathrm{N}_{3}-\mathrm{N}$. Ground water containing more than $10 \mathrm{mg} / \mathrm{L} \mathrm{NO}_{3}-\mathrm{N}$, the maximum contaminant level for drinking water (U.S. Environmental Protection Agency, 1986), was found throughout the study area. Water from more than 30 percent of the sampled wells contained nitrate concentrations in excess of the drinking water standard. Generally, the greatest nitrate concentrations were found in the upper parts of the water-table aquifer, and concentrations decreased with depth.

Nitrate concentrations in ground water at some locations have increased by as much as two orders of magnitude since the early 1950 s. In many instances, nitrate concentrations showed substantial increases within a few years of the start of irrigated agriculture. Existing data are not sufficient to determine if nitrate concentrations are generally continuing to increase or have reached equilibrium.

Three potential sources of nitrate in the ground water were investigated: (1) imported water used for irrigation, (2) naturally occurring nitrate in the soils, and (3) applied nitrogen fertilizers. Livestock and septic systems, which are potential sources of nitrate, were not investigated because they are sparsely distributed in the study area and their effects are most likely localized.

\section{Imported Irrigation Water as a Source of Nitrate in Ground Water}

Surface-water irrigation systems supply nearly 90 percent of the water used in the study area. These systems supply a major part of the ground-water recharge in the study area, through both seepage from the distribution systems and percolation of applied water. Nitrate in the surface waters is therefore added to the ground water with recharge. Because nitrate concentrations in these imported surface waters are small (median concentration of $0.88 \mathrm{mg} / \mathrm{L} \mathrm{NO}_{3}-\mathrm{N}$ ), it is clear that these waters are not the source of elevated nitrate concentrations in the ground water. In fact, seepage from the irrigation canals dilutes nitrate already present in the ground water, which is reflected in lower concentrations observed in water from wells nearer to the canals.

\section{Naturally Occurring Sources of Nitrate in Ground Water}

Forty-four samples of soil and underlying sediments from the fine-grained Hanford formation or Ringold Formation were collected at six sites on undeveloped land in or immediately adjacent to the study area. The samples were analyzed for nitrate concentration, which ranged from 0.3 to $24.3 \mathrm{mg} / \mathrm{kg} \mathrm{NO}{ }_{3}-\mathrm{N}$ with a median concentration of $1.3 \mathrm{mg} / \mathrm{kg} \mathrm{NO}_{3}-\mathrm{N}$.

Conclusions regarding natural nitrate as a source of nitrate in ground water are tentative and location specific. The small concentrations of natural nitrate in soils and sediments, and small pre-development concentrations of nitrate in ground water, suggest that amounts of natural nitrate presently in ground water are small. The leaching of natural nitrate salts by recharge from irrigation water may have caused temporary increases in nitrate concentrations observed in some areas. The temporary nature of the concentration increases suggests that if natural nitrate salts were present, they have probably been flushed into the ground water, diluted, and do not represent a significant ongoing source of nitrate.

\section{Eertilizers as a Source of Nitrate in Ground Water}

The general spatial correlation between irrigated cropland and the occurrence of nitrate in ground water at concentrations equal to or greater than the drinking water standard (fig. 8) suggests that agricultural activities are a major source of nitrate in ground water. Most of the non- irrigated sampling sites where nitrate concentrations exceed $10 \mathrm{mg} / \mathrm{L}$ are immediately downgradient of irrigated cropland. Many of the conditions conducive to the leaching of nitrogen fertilizers to ground water are present in the study area: many of the irrigated crops require large quantities 
of nitrogen fertilizers; recharge from applied irrigation water is estimated to make up about 30 percent of the ground-water budget; in many locations the depth to ground water is less than $20 \mathrm{ft}$; and soils are typically coarse textured.

Determining whether fertilizers were a source of nitrate in ground water was done by determining the nitrate concentrations in shallow ground water beneath irrigated fields at locations remote from other sources of nitrate. Water samples collected from eight piezometers open to the water-table aquifer immediately below fertilized fields had a median nitrate concentration of $22.5 \mathrm{mg} / \mathrm{L} \mathrm{NO}_{3}-\mathrm{N}$. Water samples collected from 38 subsurface drains below fertilized and irrigated fields had an average concentration of $9.6 \mathrm{mg} / \mathrm{L} \mathrm{NO} \mathrm{N}_{3}-\mathrm{N}$. Subsurface drains collect seepage from canals (low nitrate concentration) as well as deep-percolation water that has infiltrated through irrigated and fertilized fields. 


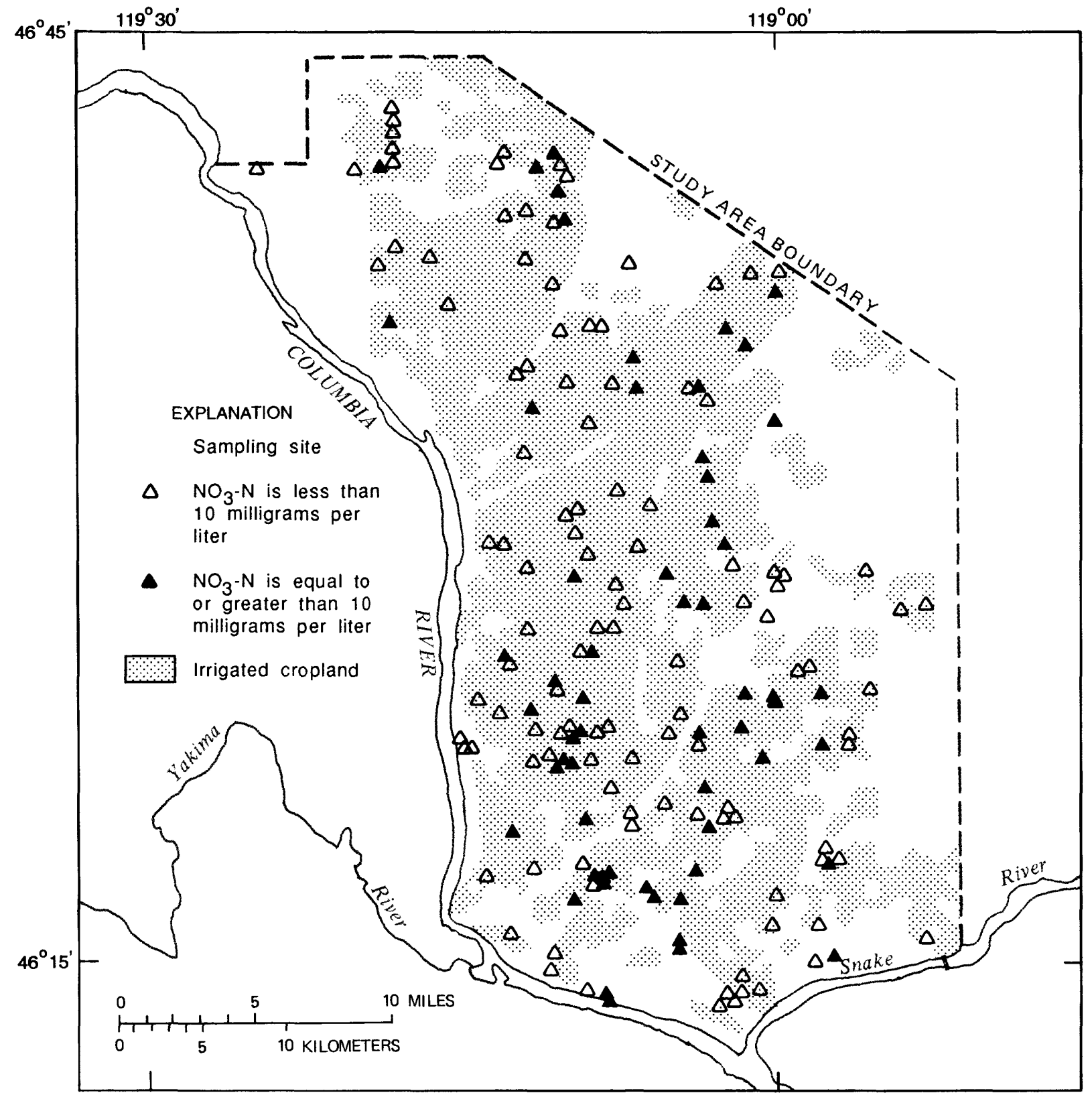

Base from U.S. Geological Survey

State base map, 1:500,000

FIGURE 8.--Location of irrigated cropland and wells tested for nitrate-ntrogen concentrations in ground water, September 1986 - November 1989. 


\section{GEOHYDROLOGIC FACTORS TO CONSIDER REGARDING MANAGEMENT OF WATER RESOURCES}

The greatest problems that confront water managers in the study area are shallow ground water that causes water-logged soils, and large concentrations of nitrate in the ground water, which is commonly used for domestic water supplies. The primary causes of shallow ground water are recharge from canal seepage and applied irrigation. The primary source of nitrates in the ground water is applied nitrogen fertilizer.

To address the problem of shallow ground water, more than $900 \mathrm{mi}$ of buried drain systems have been installed to maintain the water table below the root zone of crops. Many more miles of drains might be needed to lower water tables in other parts of the study area. However, the installation of drains deals only with the effects and not the causes. Reducing recharge would reduce the area affected by shallow ground water and would reduce the need for drain systems.

The proper timing and amount of irrigation can produce a significant decrease in recharge to the ground-water system with no loss in agricultural productivity (Franklin Conservation District, 1989). This approach also leads to a decrease in the nitrate load to the ground water, because less fertilizer is leached below the root zone of crops.

Recharge from canal seepage can be reduced by lining canals. Most of the irrigation canals in the study area are unlined, and seepage from unlined canals in the study area generally occurs at rates of at least twice (and as much as eight times) the rate from lined canals.

Some of the consequences of reducing recharge and lowering water levels would be increased pumping lifts and decreased ground-water availability. Throughout much of the study area, domestic water supplies are obtained from shallow wells, and in some locations significant quantities of irrigation and industrial water supplies are obtained from the shallow ground-water system. A significant reduction in ground-water recharge and lowering of water levels will decrease the availability of ground water and increase the effort needed to pump it.

Reducing canal seepage would lead to greater nitrate concentrations in the ground water. The recharge from canal seepage dilutes nitrate concentrations in ground water.

A qualitative summary of the potential effects of various management alternatives on the ground-water system is shown on figure 9. 
FIGURE 9.--Qualitative assessment of expected effects on the ground-water system of selected management alternatives.

Management
altemative

\section{SUMMARY AND CONCLUSIONS}

Importing surface water for irrigation has caused massive changes in the study area's ground-water system. Water levels have risen hundreds of feet and resulted in large areas in which shallow water tables have created problems. Flow through the ground-water system has increased seven-fold from pre-development times. The ground-water system reached a new dynamic equilibrium only after an increase in ground-water storage of nearly 5 million acre-feet.

Nitrate concentrations in ground water have increased several orders of magnitude over pre-development concentrations, resulting in much of the area's ground water exceeding the drinking water standard. The principal source of this nitrate in the ground water is leaching of nitrogen fertilizers applied to crops.

The major changes in the ground-water system have been increased recharge from canal seepage and applied irrigation. Together they account for almost 90 percent of the total increase in flow through the ground-water system. More efficient irrigation practices and increased use of liners in irrigation canals could significantly reduce the recharge to the ground-water system. This in turn would lead to a lower water table and a consequent decrease in the need for buried drain systems. However, decreased canal seepage would lead to significant increases in nitrate concentrations in ground water. More efficient application of fertilizers would lead to lower nitrate concentrations. 


\section{REFERENCES}

Bauer, H.H., and Vaccaro, J.J., 1987, Documentation of a deep percolation model for estimating ground-water recharge: U.S. Geological Survey Open-File Report 86-536, 180 p.

Bauer, H.H., Vaccaro, J.J., and Lane, R.C., 1985, Maps showing ground-water levels in the Columbia River Basalt and overlying material, spring 1983, southeastern Washington: U.S. Geological Survey Water-Resources Investigations Report 84-4360, 4 sheets.

Drost, B.W., Schurr, K.M., Ruppert, G.P., and Cox, S.E., 1989, Well data, surface-water discharges, and nitrate concentrations, February 1986-September 1987, in parts of the Pasco basin, Washington: U.S. Geological Survey Open-File Report 89-38, 132 p.

Drost, B.W., and Whiteman, K.J., 1986, Surficial geology, structure, and thickness of selected geohydrologic units in the Columbia Plateau, Washington: U.S. Geological Survey Water-Resources Investigations Report 84-4326, 12 sheets.

Franklin Conservation District, 1989, Irrigation scheduling: A water-quality must: Franklin Conservation District, Pasco, Washington, 13 p.

Marratt, W.J., 1988, Study of landslides along the Columbia River in the Block 15 area of Franklin County, Washington: Franklin Conservation District, Pasco, Washington, 31 p.

Mundorff, M.J., Reis, D.J., and Strand, J.R., 1952, Progress report on ground water in the Columbia Basin Project, Washington: U.S. Geological Survey Open-File Report, 119 p., 5 pl.

Phillips, E.L., 1970, Washington climate for these counties, Asotin, Benton, Columbia, Franklin, Garfield, Walla Walla: Seattle, Washington, Washington State University, College of Agriculture, Cooperative Extensive Service, $93 \mathbf{p}$.

Schuster, R.L., and Hays, W.H., 1984, Irrigation-induced landslides in soft rocks and sediments along the Columbia River, south-central Washington State, U.S.A., IV International Symposium on landslides, Toronto, 1984: Proceedings, v. 1, p. 431-436.

U.S. Environmental Protection Agency, 1986, Quality criteria for water 1986 and update no. 1 and update no. 2 (May 1, 1987), Washington, D.C.: U.S. Environmental Protection Agency, 440/5-86-001. 